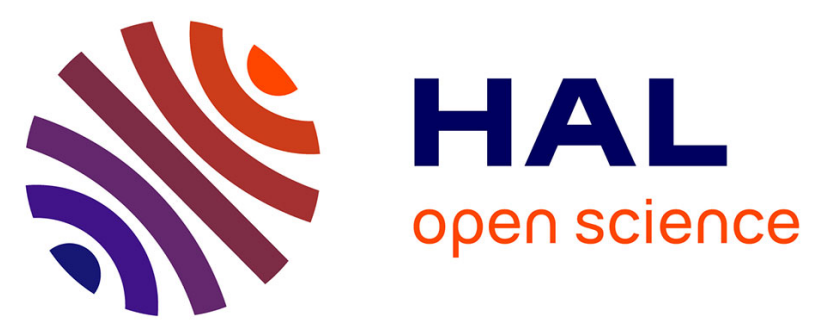

\title{
Dynamics of bacterial assemblages and removal of polycyclic aromatic hydrocarbons in oil-contaminated coastal marine sediments subjected to contrasted oxygen regimes
}

Cécile Militon, Ronan Jezequel, Franck Gilbert, Yannick Corsellis, Léa Sylvi, Cristiana Cravo-Laureau, Robert Duran, Philippe Cuny

\section{To cite this version:}

Cécile Militon, Ronan Jezequel, Franck Gilbert, Yannick Corsellis, Léa Sylvi, et al.. Dynamics of bacterial assemblages and removal of polycyclic aromatic hydrocarbons in oil-contaminated coastal marine sediments subjected to contrasted oxygen regimes. Environmental Science and Pollution Research, 2015, 22 (20), pp.15260-15272. 10.1007/s11356-015-4510-y . hal-01233392

\section{HAL Id: hal-01233392 https://hal.science/hal-01233392}

Submitted on 25 Nov 2015

HAL is a multi-disciplinary open access archive for the deposit and dissemination of scientific research documents, whether they are published or not. The documents may come from teaching and research institutions in France or abroad, or from public or private research centers.
L'archive ouverte pluridisciplinaire HAL, est destinée au dépôt et à la diffusion de documents scientifiques de niveau recherche, publiés ou non, émanant des établissements d'enseignement et de recherche français ou étrangers, des laboratoires publics ou privés. 


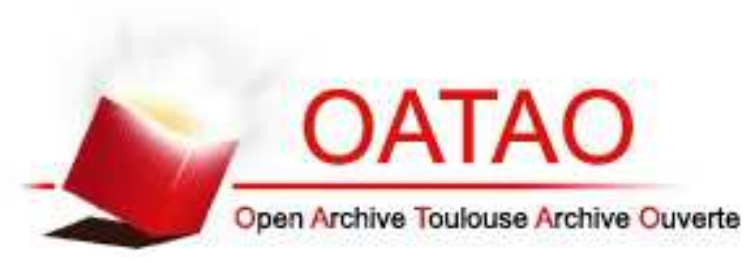

\section{Open Archive TOULOUSE Archive Ouverte (OATAO)}

OATAO is an open access repository that collects the work of Toulouse researchers and makes it freely available over the web where possible.

This is an author-deposited version published in : http://oatao.univ-toulouse.fr/ Eprints ID : 14472

To link to this article : doi: $10.1007 / \mathrm{s} 11356-015-4510-\mathrm{y}$

URL : http://dx.doi.org/10.1007/s11356-015-4510-y

To cite this version : Militon, Cécile and Jezequel, Ronan and Gilbert, Franck and Corsellis, Yannick and Sylvi, Léa and Cravo-Laureau, Cristiana and Duran, Robert and Cuny, Philippe Dynamics of bacterial assemblages and removal of polycyclic aromatic hydrocarbons in oilcontaminated coastal marine sediments subjected to contrasted oxygen regimes. (2015) Environmental Science and Pollution Research, vol. 22 $\left(\mathrm{n}^{\circ} 20\right)$. pp. 15260-15272. ISSN 0944-1344

Any correspondance concerning this service should be sent to the repository administrator: staff-oatao@ listes-diff.inp-toulouse.fr 


\title{
Dynamics of bacterial assemblages and removal of polycyclic aromatic hydrocarbons in oil-contaminated coastal marine sediments subjected to contrasted oxygen regimes
}

\author{
Cécile Militon $^{1,6} \cdot$ Ronan Jézéquel $^{2} \cdot$ Franck Gilbert $^{3,4} \cdot$ Yannick Corsellis $^{1} \cdot$ Léa Sylvi $^{1}$ • \\ Cristiana Cravo-Laureau ${ }^{5} \cdot$ Robert Duran $^{5} \cdot$ Philippe Cuny $^{1}$
}

\begin{abstract}
To study the impact of oxygen regimes on the removal of polycylic aromatic hydrocarbons (PAHs) in oil-spillaffected coastal marine sediments, we used a thin-layer incubation method to ensure that the incubated sediment was fully oxic, anoxic, or was influenced by oxic-anoxic switches without sediment stirring. Hydrocarbon content and microbial assemblages were followed during 60 days to determine PAH degradation kinetics and microbial community dynamics according to the oxygenation regimes. The highest PAH removal, with $69 \%$ reduction, was obtained at the end of the experiment under oxic conditions, whereas weaker removals were obtained under oscillating and anoxic conditions (18 and $12 \%$, respectively). Bacterial community structure during the experiment was determined using a dual $16 \mathrm{~S}$ rRNA
\end{abstract}

Responsible editor: Philippe Garrigues

Cécile Militon

cecile.militon@univ-amu.fr

1 Aix Marseille Université, CNRS/INSU, Université de Toulon, IRD, Mediterranean Institute of Oceanography (MIO) UM 110, 13288 Marseille, France

2 Centre de Documentation, de Recherche et d'Expérimentations sur les pollutions accidentelles des Eaux, 715 rue Alain Colas, CS 41836, 29218 Brest, France

3 Université de Toulouse; INP, UPS; EcoLab (Laboratoire écologie fonctionnelle et environnement), 118 Route de Narbonne, 31062 Toulouse, France

4 CNRS; EcoLab, 31062 Toulouse, France

5 Equipe Environnement et Microbiologie, MELODY group, Université de Pau et des Pays de l'Adour, IPREM UMR CNRS 5254, BP 1155, 64013 Pau Cedex, France

6 Campus de Luminy, case 901, 163 avenue de Luminy, 13288 Marseille Cedex 09, France
genes/16S rRNA transcripts approach, allowing the characterization of metabolically active bacteria responsible for the functioning of the bacterial community in the contaminated sediment. The shift of the metabolically active bacterial communities showed that the selection of first responders belonged to Pseudomonas spp. and Labrenzia sp. and included an unidentified Deltaproteobacteria-irrespective of the oxygen regime - followed by the selection of late responders adapted to the oxygen regime. A novel unaffiliated phylotype (B38) was highly active during the last stage of the experiment, at which time, the low-molecular-weight (LMW) PAH biodegradation rates were significant for permanent oxic- and oxygen-oscillating conditions, suggesting that this novel phylotype plays an active role during the restoration phase of the studied ecosystem.

Keywords Oxic/anoxic oscillation · Aerobic and anaerobic hydrocarbon degradation $\cdot$ PAHs $\cdot$ Marine sediment $\cdot$ Bacterial communities · DGGE $\cdot$ Dual 16S rRNA/rRNA gene

\section{Introduction}

Polycyclic aromatic hydrocarbons (PAHs) are widespread in marine sediments as a result of both natural processes (usually occurring in the range $0.01-1 \mathrm{ng} / \mathrm{g}$ dry weight) and of human activities (e.g., industrial production, accidental leakages during polluting transport/storage, and waste incineration). These organic compounds are frequently measured at increasing levels in marine sediments, particularly in coastal areas subject to anthropogenic pressures (Nikolaou et al. 2009). PAHs are persistent toxic molecules, several of which highly impact human and environmental health (Cerniglia and Heitkamp 1989; Hylland 2006). Their fate in marine sediment has thus attracted the attention of the scientific community. Among the 
abiotic and biotic factors controlling hydrocarbon (HC) degradation and preservation (e.g., substrate quality, sediment character, and redox effects on microbial degradation), oxygen availability appears to be a key control (Cuny et al. 2011). Indeed, this molecule, in addition to being the most favorable terminal electron acceptor during $\mathrm{HC}$ oxidation, is one of the key reactants for $\mathrm{HC}$ activation and, therefore, for $\mathrm{HC}$ biodegradation (Rojo 2010). Removal of PAHs from contaminated aerobic ecosystems has been intensively studied for decades, and major routes for microbial aerobic biodegradation of PAHs are now well described (Pérez-Pantoja et al. 2010). Nevertheless, as HCs can be passively or actively buried in sediments (by sedimentation or through the action of macrobenthic organisms, respectively), they are quickly trapped in suboxic or anoxic layers. Indeed, as oxygen typically penetrates only a few millimeters into coastal sediments, these habitats are largely devoid of molecular oxygen. Moreover, due to the slow oxygen turnover in watersaturated systems, superficial sediments react rapidly to organic carbon inputs and, as a result, become mostly anoxic. By contrast, the mechanisms involved in PAH removal under anaerobic conditions have been the subject of much less investigation, despite the importance of this process in marine sediments. During the last two decades, most studies on HC degradation processes have been performed under strictly oxic or anoxic conditions (for reviews see Meckenstock and Mouttaki 2011; Fuch et al. 2011), and it is striking to note how little attention has been paid to oxygen-oscillating conditions, although they are widespread in these environments. In coastal marine sediments, these oxygen pulses often occur at timescales of minutes to months in response to tidal excursions, storm events, or macrofaunal burrowing and ventilation activities (Wakeham and Canuel 2006; Pischedda et al. 2008). The impact of oxygen oscillations on HC degradation has been indirectly observed in experiments studying the influence of bioturbation on the preservation/degradation of HCs in marine sediments (Gilbert et al. 1996; Grossi et al. 2002; Miralles et al. 2007) with no precise measurement of how the oxic/anoxic switches influence these processes. The influence of oxic/anoxic oscillations on organic matter (OM) preservation and mineralization in marine sediments has been almost exclusively studied on terrestrial-derived and marine-borne OM. These studies have highlighted that the decomposition rate of $\mathrm{OM}$ that has experienced switches from anoxic to oxic states may be promoted relative to steady anoxic conditions (Sun et al. 2002; Bastviken et al. 2004) and that even if oscillating conditions do not increase OM mineralization, anoxic to oxic switches enhance OM degradation during the subsequent oxic phases (Bastviken et al. 2004; Abril et al. 2010). A small number of previous studies have focused on the fate of HCs under oxic/anoxic switches as an alternative cost-effective bioremediation process using simplified bacterial consortia (Löser et al. 1998; Vieira et al. 2009; Vitte et al. 2011) or native microbial communities from oil-contaminated sludge (Vitte et al. 2013). These studies, which have focused on PAH degradation under oscillating oxygen, steady oxic, and/or steady anoxic conditions in bioreactors, have so far reached contrasting conclusions. Löser et al. (1998) and Vitte et al. (2011, 2013) found no difference in PAH removal between oxic and oscillating conditions when they used, respectively, a pilot-scale plant with diesel-fuel-contaminated sand and a bioreactor filled with sludge from a contaminated environment. In contrast, Vieira et al. (2009) observed that the oscillating oxygen conditions enhanced $\mathrm{HC}$ removal in experiments using effluent from a contaminated lagoon. Although these studies carefully addressed the role of oxygen oscillations in the fate of HCs and in their degradation, they used experimental approaches (a slurry bioreactor or a pilotscale plant) dedicated to ex situ bioremediation processes increasing mass transfer rates (i.e., pollutant desorption), increasing microorganism/pollutant/nutrient contact, and, consequently, increasing rates of pollutant biodegradation when compared to in situ bioremediation.

To gain insight into the influence of oxygen regimes on the degradation of PAHs present in crude oil released into coastal marine environments, surficial sediment was experimentally contaminated with crude oil and incubated in field-simulating microcosms using the plug technique. This thin-layer incubation technique ensures that the incubated sediment is fully oxic, anoxic, or influenced by oxic-anoxic switches without sediment stirring (Sun et al. 1993; Aller 1994; Kristensen et al. 1995). The fate of PAHs was monitored during 60 days under three schemes of oxygenation (steady oxic, steady anoxic conditions, and oxic/anoxic oscillations). In this paper, we also report the changes taking place in microbenthic communities under selective pressures exerted by both crude oil and by oxygen regimes. The dynamic of the microbial community was analyzed in different oxygen regimes using a dual $16 \mathrm{~S}$ ribosomal DNA (rRNA)/16S rRNA gene denaturing gradient gel electrophoresis (DGGE) approach, allowing the characterization of total bacteria and of metabolically active bacteria.

\section{Materials and methods}

Sediments and experimental setup Microcosms were established with mudflat sediment recovered from the Aber Benoît basin (Treglonou, France). The amount of carbon bound in organic compounds in this sediment was $6.8 \%$. The sediment ( $\mathrm{pH} 7.7$ ), composed of $3 \%$ clay, $31 \%$ silt, and $66 \%$ sand, was contaminated with 20,000 ppm of oil (BAL 110, Arabian Light crude oil topped at $110^{\circ} \mathrm{C}$ ). The oiled sediment was spread in a 2 -mm layer in 12 crystallizers $(\varnothing=28 \mathrm{~cm}, \mathrm{~h}=15 \mathrm{~cm})$ and covered by $9 \mathrm{~L}$ of synthetic sterilized seawater containing the following $\left(\mathrm{g} \mathrm{L}^{-1}\right.$ in distilled water): Tris, $2 ; \mathrm{NaCl}, 23 ; \mathrm{KCl}, 0.75 ; \mathrm{NH}_{4} \mathrm{Cl}, 1 ; \mathrm{MgSO}_{4} \cdot 7 \mathrm{H}_{2} \mathrm{O}$, 
6.16; $\mathrm{MgCl}_{2} \cdot 6 \mathrm{H}_{2} \mathrm{O}, 5.08$; and $\mathrm{CaCl}_{2} \cdot 2 \mathrm{H}_{2} \mathrm{O}, 1.5(\mathrm{pH} 7.7)$. Three conditions were applied over four microcosms, as illustrated in Fig. 1: (i) permanent oxygenation (Ox) and (ii) permanent anoxia (An), maintained, respectively, by continual purging of the water microcosms with sterile air and with an $\mathrm{N}_{2} / \mathrm{CO}_{2}$ mixture and (iii) oscillation between oxic and anoxic conditions (Osc), performed by switching purging gas in water reservoirs according to the following regime: 3 days of oxia/3 days of anoxia. The incubations were carried out for 2 months at room temperature (mean $19.4{ }^{\circ} \mathrm{C}$, std. $0.8^{\circ} \mathrm{C}$ ) in darkness to avoid $\mathrm{HC}$ photodegradation. The $\mathrm{HC}$ content and the microbial assemblages were monitored for the sampling times T0 (initial sampling), T1(15 days), T2 (30 days), T3 (45 days), and T4 (60 days) in order to determine the degradation kinetics and the dynamics of the microbial communities for each oxygenation regime. Thus, for each sampling time (with the exception of T0), three crystallizers were collected (one per oxygenation regime). Sediments were sampled, homogenized, and conditioned for microbiological and $\mathrm{HC}$ analyses.

HC analyses Two-gram sediment samples were spiked with one aliphatic perdeuterated and five aromatic perdeuterated hydrocarbon surrogate standards (LGC standard, Molsheim, France) and then extracted with $30 \mathrm{~mL}$ methylene chloride at $100{ }^{\circ} \mathrm{C}$ and 2000 psi for $14 \mathrm{~min}$ in a Dionex ASE 200 accelerated solvent extractor. Sediment extractions were performed twice for each sample. Organic extracts were dried over
$\mathrm{Na}_{2} \mathrm{SO}_{4}$ (activated at $400{ }^{\circ} \mathrm{C}$ during $4 \mathrm{~h}$ ) and concentrated to approximately $2 \mathrm{~mL}$ using a Syncore (Büchi, Germany). Extracts were fractionated using a solid-phase extraction (SPE) cartridge ( silica/cyanopropyl $\left(\mathrm{SiO}_{2} / \mathrm{C} 3-\mathrm{CN}\right)(1.0 / 0.5 \mathrm{~g}$, $6 \mathrm{~mL}$ ) (Interchim, Montluçon, France)) (Alzaga et al. 2004): fractions of saturates and aromatics were eluted simultaneously with $8 \mathrm{~mL}$ of methylene chloride/pentane (80:20, v/v) and concentrated to approximately $2 \mathrm{~mL}$. Alkanes and aromatics were quantified using gas chromatography coupled with mass spectrometry (GC/MS). The GC was an HP 6890N (HewlettPackard, Palo Alto, CA, USA) equipped with a split/splitless injector (splitless time $1 \mathrm{~min}$, flow $50 \mathrm{~mL} / \mathrm{min}$ ). The injector temperature was maintained at $300{ }^{\circ} \mathrm{C}$. The interface temperature was $300{ }^{\circ} \mathrm{C}$. The $\mathrm{GC}$ temperature gradient was from $50{ }^{\circ} \mathrm{C}(1 \mathrm{~min})$ to $300{ }^{\circ} \mathrm{C}(20 \mathrm{~min})$ at $5{ }^{\circ} \mathrm{C} / \mathrm{min}$. The carrier gas was helium at a constant flow of $1 \mathrm{~mL} / \mathrm{min}$. The capillary column used was a HP-5 MS (HP, Palo Alto, USA): $30 \mathrm{~m} \times$ $0.25-\mathrm{mm}$ ID $\times 0.25-\mu \mathrm{m}$ film thickness. The GC was coupled to an HP 5973 Mass Selective Detector (MSD) (electronic impact $70 \mathrm{eV}$, voltage $1200 \mathrm{~V})$. $n$-alkanes and $\mathrm{PAH}$ semiquantifications were done using single ion monitoring (SIM) mode with the most representative fragment (saturates) or the molecular ion (PAH) of each compound at a minimum of 1.4 cycles/s.

Nucleic acid recovery Total RNA and DNA were coextracted and purified from $2 \mathrm{~g}$ of sediment in triplicate using the RNA PowerSoil Total RNA Isolation kit and the RNA
Fig. 1 Experimental setup. For each oxygen regime, four thinlayer incubation microcosms (a) were prepared and incubated under permanent oxygenation (oxic) maintained by continual purging of the water microcosms with sterile air (white arrows), permanent anoxia (anoxic) maintained by continual purging of the water microcosms using an $\mathrm{N}_{2} / \mathrm{CO}_{2}$ mixture (black arrows), and by the oscillation between oxic and anoxic conditions (Oscillation) performed by switching purging gas in water reservoirs according the following regime: 3 days of oxia/3 days of anoxia (b). At each sampling time (T0, T1, T2, T3, and T4) and for each treatment, sediments coming from one of the microcosms were sampled

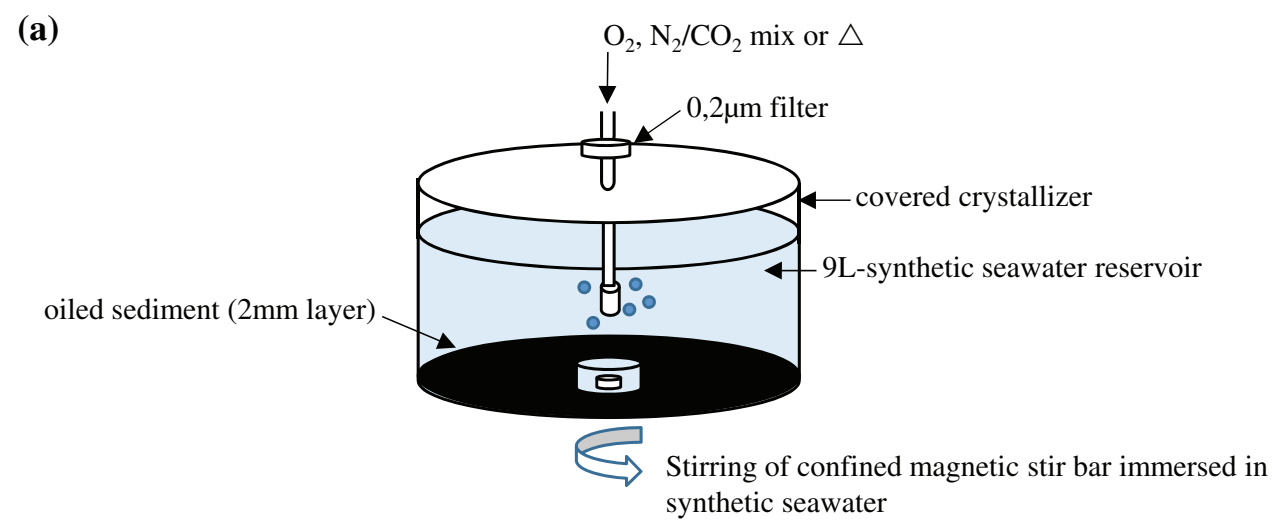

(b)

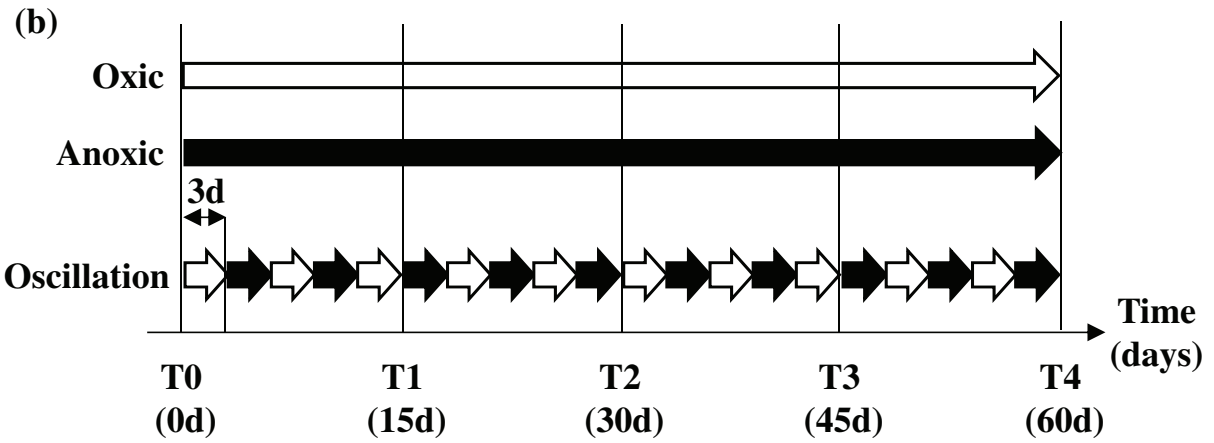


PowerSoil DNA Elution Accessory kit (MoBio, Carlsbad, CA, USA) according to the manufacturer's recommendations. Residual DNA in the RNA samples was removed with $4 \mathrm{U}$ RNase-free DNase I (Invitrogen ${ }^{\mathrm{TM}}$ ). The complete removal of DNA was checked by a control PCR using the bacterial primers on recovered RNA (PCR conditions described below). Total RNA was analyzed on the 2100 Bioanalyzer $^{\circledR}$ (RNA 6000 Nano Kit, Agilent Technologies) as recommended by the manufacturer. DNA purity and concentration were checked using a BioSpec-nano spectrophotometer (Shimadzu). The RNA and DNA solutions were stored at -80 and $-20{ }^{\circ} \mathrm{C}$, respectively.

Reverse transcription polymerase chain reaction of $16 \mathrm{~S}$ rRNA Denatured total RNA (125 ng) was reverse transcribed using the MasterScript kit (5 Prime) according to the manufacturer's recommendations and the $16 \mathrm{~S}$ reverse primer Uni_1492R (5'-TACGYTACCTTGTTACGACTT3') (Lane 1991). PCR amplifications were performed using the primer set Uni_1492R and 27F (5'-AGAGTTTGATCC TGGCTCAG-3') (Lane 1991). The 50- $\mu$ L reaction mixture contained $1 \mu \mathrm{M}$ of each primer, $0.2 \mu \mathrm{M}$ deoxynucleotide triphosphate (dNTP), $20 \mathrm{ng}$ of RT products, $0.75 \mathrm{U}$ of Taq polymerase (5 Prime), and $1 \times$ of the recommended buffer (5 Prime). The reactions were performed in an iCycler thermocycler (Bio-Rad) using a program with an initial denaturation step for $3 \mathrm{~min}$ at $94{ }^{\circ} \mathrm{C}$, followed by 30 cycles of three steps $\left(94{ }^{\circ} \mathrm{C}\right.$ for $1 \mathrm{~min}, 50{ }^{\circ} \mathrm{C}$ for $1 \mathrm{~min}, 72{ }^{\circ} \mathrm{C}$ for $2 \mathrm{~min}$ ) and a final extension step for $5 \mathrm{~min}$ at $72{ }^{\circ} \mathrm{C}$. Nested PCR was then performed as described previously on fulllength $16 \mathrm{~S}$ rRNA genes $(5 \mu \mathrm{L})$ using the bacterial primer set 907RA (5'-CCGTCAATTCMTTTRAGTTT-3') (Lane et al. 1985) and GML5F containing a GC clamp (underlined) (5'-CGCCCGCCGCGCCCCGCGCCCGTC CCGCCGCCCCCGCCCGCCGCCTACGGGAGGCAGG AG-3') (Muyzer et al. 1993). The reactions were performed using a touchdown program with an initial denaturation step for $5 \mathrm{~min}$ at $94{ }^{\circ} \mathrm{C}$, followed by 20 cycles of three steps $\left(94{ }^{\circ} \mathrm{C}\right.$ for $1 \mathrm{~min}, 60^{\circ} \mathrm{C}$ for $1 \mathrm{~min}$ that reduced onehalf degree per cycle, $72{ }^{\circ} \mathrm{C}$ for $2 \mathrm{~min}$ ). Finally, 14 cycles of three steps were performed $\left(94{ }^{\circ} \mathrm{C}\right.$ for $1 \mathrm{~min}, 50{ }^{\circ} \mathrm{C}$ for $1 \mathrm{~min}, 72{ }^{\circ} \mathrm{C}$ for $2 \mathrm{~min}$ ) followed by a final extension step for $5 \mathrm{~min}$ at $72{ }^{\circ} \mathrm{C}$. PCR products were visualized and quantified by agarose gel electrophoresis.

PCR amplification of the 16S rRNA genes PCR amplifications were performed using the bacterial primer set and the programs used for the nested PCR amplification (described above). The $50-\mu \mathrm{L}$ reaction mixture contained $1 \times$ tuning buffer, $1 \mu \mathrm{M}$ of each primer, $0.2 \mu \mathrm{M}$ dNTP, $1.5 \mathrm{U}$ PCR extender polymerase (5 Prime), $2 \mu \mathrm{g}$ T4 gene 32 protein (Roche), and 10 ng DNA. PCR products were visualized and quantified by agarose gel electrophoresis.
DNA fingerprinting by DGGE Eight hundred nanograms of PCR products was loaded on a $6 \%$ acrylamide gel with a 30 $50 \%$ denaturing gradient for the bacterial fingerprints (where $100 \%$ denaturant contained $7 \mathrm{M}$ urea and $40 \%$ deionized formamide). Electrophoresis was conducted in $7 \mathrm{~L}$ of TAE $1 \times\left(40 \mathrm{mM}\right.$ Tris acetate, $\mathrm{pH} 8.0,1 \mathrm{mM} \mathrm{Na}{ }_{2}$ EDTA $)$ in a BioRad Dcode system ${ }^{\circledR}$ (Bio-Rad, USA) at $180 \mathrm{~V}$ at $60{ }^{\circ} \mathrm{C}$ for $280 \mathrm{~min}$. After electrophoresis, the gel was stained with $20 \mu \mathrm{g}$ of ethidium bromide diluted in $400 \mathrm{~mL}$ of TAE $1 \times$ and visualized on a UV transilluminator. Bacterial profiles were numerized using the Gel Doc $2000^{\circledR}$ system (Bio-Rad).

DGGE band isolation and sequencing DNA bands were cut out of the DGGE gel and eluted overnight in $20 \mu \mathrm{L}$ of molecular-grade water at $4{ }^{\circ} \mathrm{C}$. Two microliters of elution was re-amplified as described previously (nested PCR amplification protocol) using primer sets without the GC clamp under the following conditions: (i) an initial denaturation step for $3 \mathrm{~min}$ at $94{ }^{\circ} \mathrm{C}$ followed by (ii) 30 cycles of three steps $\left(94{ }^{\circ} \mathrm{C}\right.$ for $30 \mathrm{~s}, 55^{\circ} \mathrm{C}$ for $30 \mathrm{~s}, 72{ }^{\circ} \mathrm{C}$ for $40 \mathrm{~s}$ ) followed by a final extension step for $2 \mathrm{~min}$ at $72{ }^{\circ} \mathrm{C}$. PCR products were visualized using agarose gel electrophoresis and purified with the Wizard ${ }^{\mathbb{B}}$ SV Gel and PCR Clean-Up System (Promega) as suggested by the manufacturer. Purified DNA was sequenced by GATC Biotech (Konstanz, Germany).

Sequence treatment and statistical analyses Molecular data treatment was performed using the MEGA5 program (Tamura et al. 2011). The sequences were compared with the GenBank nucleotide database using the BLASTN algorithm (Altschul et al. 1990). Sequences were checked for chimeric PCR artifacts using DECIPHER (Wright et al. 2012). Multiple sequence alignment was performed using the CLUSTAL W program (Thompson et al. 1994). Phylogenies were reconstructed using the neighbor-joining method (Saitou and Nei 1987) and Kimura's two-parameter model (Kimura 1980). Bootstrap analysis was performed with 1000 resampled datasets to determine the statistical significance of the branching order. DGGE band profiles were analyzed with GelComparII (Applied Maths, Belgium). Fingerprints of the bacterial communities were subjected to principal component analysis (PCA) with the FactoMineR package (Lê et al. 2008) with software R.2.11.1 to summarize and simplify the data by reducing the dimensionality of the community structures. Similarity coefficient calculations based upon band positions and their relative intensity (Pearson coefficient) allowed the creation of dendrograms using the arithmetic mean algorithm (UPGMA).

Nucleotide sequence accession numbers The sequences determined in this study have been submitted to the GenBank database under Accession Nos. KM405449 to KM405514. 
(a)

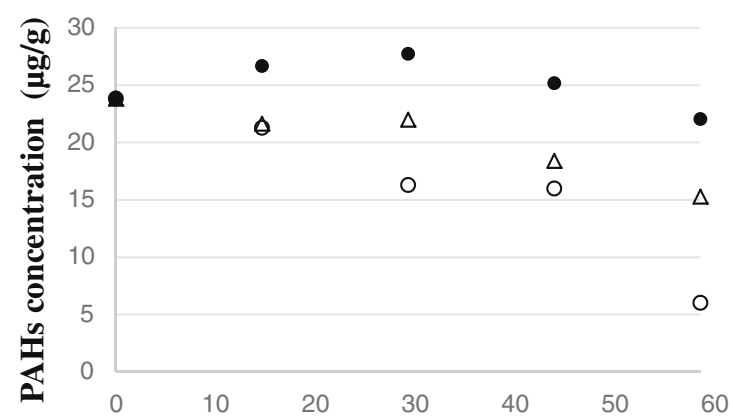

(c)

Time (days)

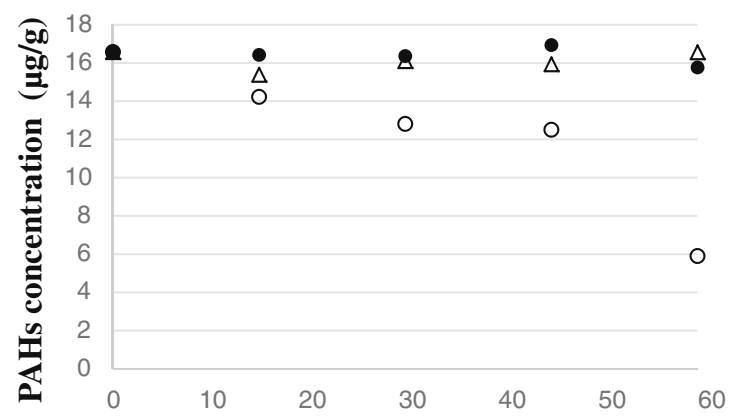

Time (days)

(e)

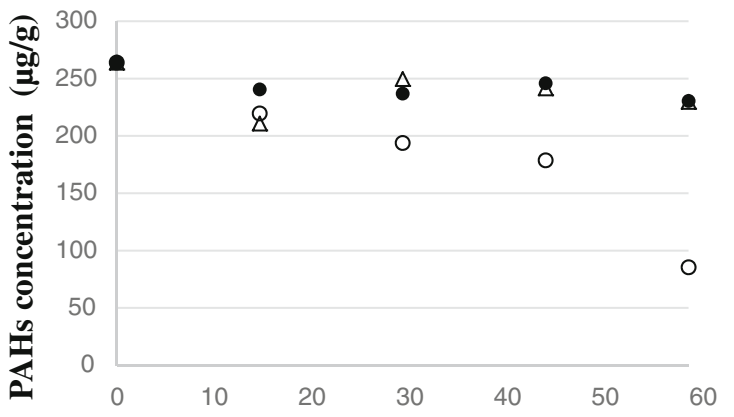

(g)

Time (days)

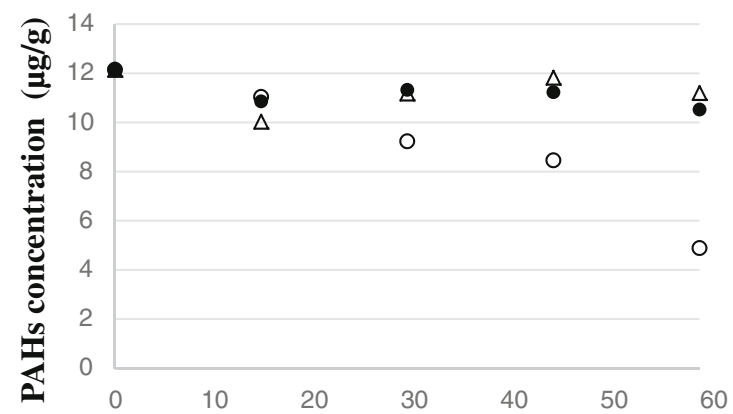

Time (days)

Fig. 2 PAHs remaining in the sediments exposed to permanent oxygenation (white circle), to oscillation between oxic and anoxic conditions (white up-pointing triangle) and to permanent anoxia (black circle). Studied families (parent and alkylated forms) are (b)

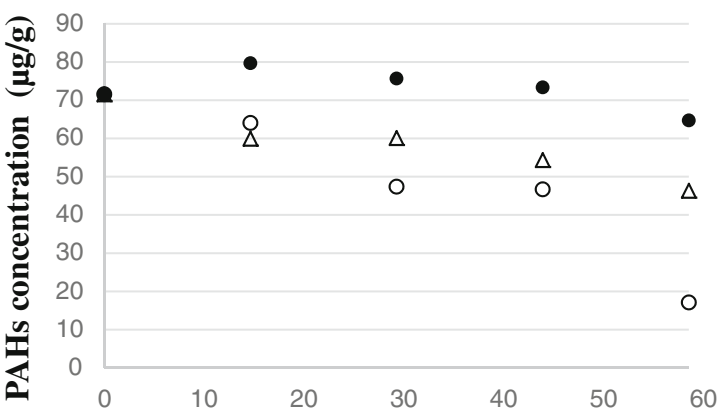

Time (days)

(d)

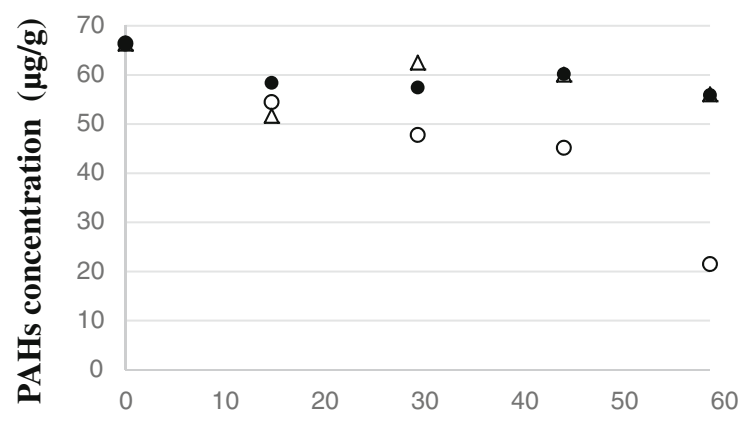

Time (days)

(f)

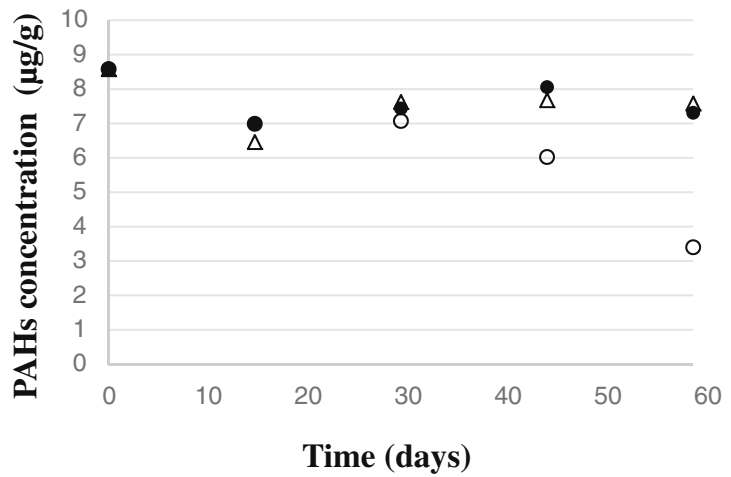

benzo(b)thiophene (a); naphthalene (b), biphenyl, acenaphthylene, acenaphtene, and fluorene (c); phenanthrene and anthracene (d); dibenzothiophene (e); fluoranthene and pyrene (f); and benzo[a]anthracene and chrysene (g) 


\section{Results and discussion}

\section{Effect of oxygenation regimes on removal of PAH}

Due to the small quantity of sediment used in each microcosm (plug technique), after sampling the sediment for the nucleic acids extractions, all the remaining sediment had to be used for the chemical analysis and results are given from only one replicate. However, Stauffert et al. (2013), using sediments from the same tidal flat and the same analytical procedure, obtained highly reproducible results for the HC analyses between replicate samples. We therefore assume that the presented chemical results are representative of the dynamics of HCs under the different oxygenation regimes. The concentrations of $n$-alkanes (n-C10 to $n$-C38) and total PAHs in the sediment at the initial sampling (T0) were 2,620 and $466 \mu \mathrm{gg}^{-1}$ of dry weight, respectively. Medium chain-length $n$-alkanes $(n-\mathrm{C} 10$ to $n$-C17) represented $40 \%$ of the alkanes, whereas two-, three-, four- and five-aromatic-ring HCs represented 20.5, 62.0, 16.9, and $0.1 \%$ of total PAHs, respectively (Fig. 2). As expected, the alkylated derivatives of PAHs were more abundant than the parent compounds in the studied families. After 2 months, the determination of residual HCs showed removal efficiencies of $n$-alkanes of 32, 21, and $13 \%$ under permanent oxic, oxic/anoxic oscillating, and permanent anoxic conditions, respectively (Fig. 3). As shown in Fig. 2, PAHs were partially depleted at the end of the experiment in the oxic condition (69\%) although they were weakly or not depleted in the oscillating (18\%) and the anoxic (12\%) conditions. Different trends have been reported in previous studies focusing on the effect of oxygenation regimes in determining the fate of HCs (Löser et al. 1998; Vieira et al. 2009; Vitte et al. 2011, 2013). Löser et al. (1998) observed that less than $50 \%$ of diesel fuel was removed in 4 weeks, irrespective of the condition (oxic and oscillating conditions) when using a pilot-scale plant with diesel-fuel-contaminated sand ( $3 \mathrm{~g} / \mathrm{kg})$. The results obtained by Löser et al. (1998) are in accordance with those reported by Vitte et al. $(2011,2013)$ who examined sludge from a contaminated environment using a bioreactor. They concluded that removal efficiency was the same under permanent oxygenation and anoxic/oxic alternations, obtaining removal of $98 \%$ of PAHs in 3 weeks and up to $80 \%$ under permanent anoxic conditions. In contrast, Vieira et al. (2009) used effluent from a contaminated lagoon to reveal improved efficiency of diesel fuel and gasoline removal under conditions of intermittent aeration (90\% removal of total HCs) rather than under constant aeration or without aeration (84 and $70 \%$ removal, respectively) after 3 weeks. Among the biodegradation results for identifiable HC classes, these authors also observed n-alkane removals of 99.6, 98.5, and $76.8 \%$ under conditions of intermittent, constant, and no aeration, respectively. In comparison to results obtained in our study, all these works show, on one hand, greater HC removal irrespective of aeration condition and, on the other hand, nearidentical removal efficiencies under permanent oxygenation and oxic/anoxic alternations. The different results obtained by our study and the previous ones are mainly due to the lack of contaminated sediment resuspension in the thin-layer experimental device (Fig. 1). Indeed, sediment resuspension has been shown to increase the remobilization of sediment-sorbed pollutants (Latimer et al. 1999) and the bacterial mineralization of HCs (Leblanc et al. 2006) due to the increase of the desorbed fraction of PAH compounds available for bacterial uptake (Cerniglia and Heitkamp 1989).

Under permanent oxygenation, the fate of the different PAH families followed the same downward trend during the experiment, with an acceleration of PAH removal from 45 to 60 days (T3 to T4) (Fig. 2). Benzo(b)thiophene (Fig. 2a) and naphthalene (Fig. 2b) (two-aromatic fused ring PAHs) showed the greatest depletion with 75 and
Fig. $3 N$-alkanes ( $n$-C10 to $n$ C38) remaining in the sediments exposed to permanent oxygenation (white circle), to oscillation between oxic and anoxic conditions (white uppointing triangle), and to permanent anoxia (black circle)

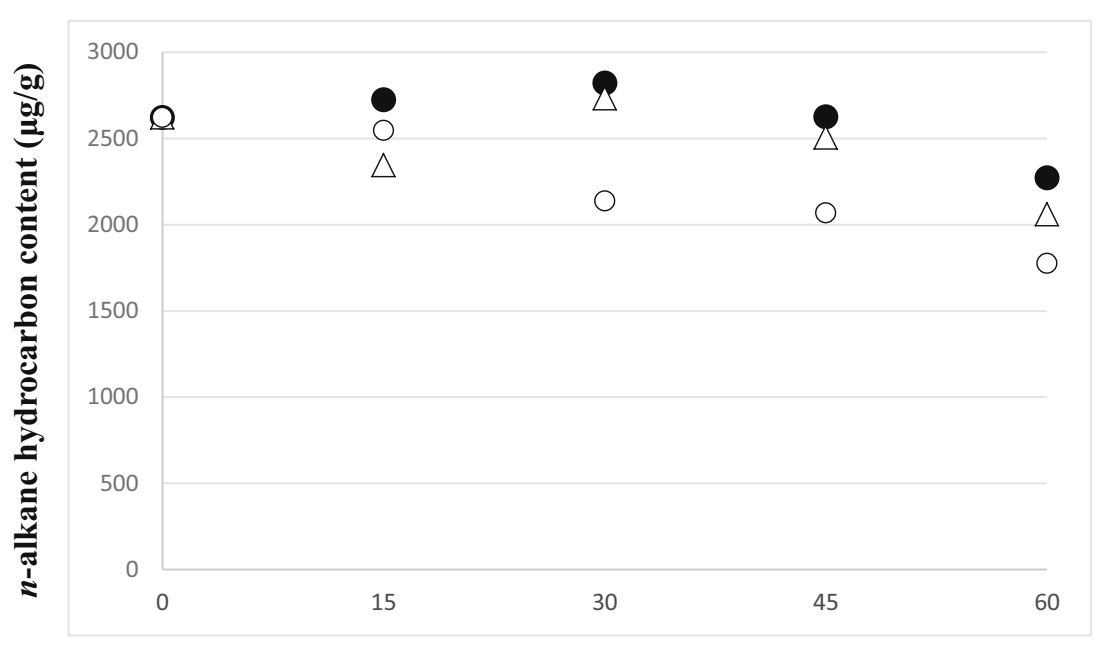

Time (days) 
$76 \%$ removal after 60 days (T4), respectively. The threearomatic fused ring PAHs (biphenyl, acenaphthylene, acenaphthene, fluorine: Fig. 2c; phenanthrene, anthracene: Fig. 2d; and dibenzothiophene: Fig. 2e) and the highmolecular-weight PAHs (fluroanthene, pyrene: Fig. 2f; benzo[a]anthracene and chrysene: Fig. $2 \mathrm{~g}$ ) showed weaker depletion after 2 months (T4) with 64-68 and $60 \%$ removal, respectively. Under oscillation between oxic and anoxic conditions, only the lighter PAHs (benzo(b)thiophene and naphthalene-(Fig. 2a, b) showed significant depletion, which began after 45 days (T3) for both compounds. After 60 days (T4), 35 and $36 \%$ of benzo(b)thiophene and naphthalene were removed, respectively. Under both conditions, the removal of PAHs (especially for two- and three-aromatic ring PAHs) was due to a combination of microbial-mediated degradation processes and abiotic elimination such as PAH evaporation by air stripping. The order of susceptibility of PAH families to degradation was in accordance with those generally reported (Leahy and Colwell 1990; Head et al. 2006). Low-molecularweight (LMW) PAHs ( $<3$ rings) are degraded and volatilized more rapidly than high-molecular-weight (HMW) PAHs (>3 rings) because as molecular weight increases, vapor pressure and solubility decrease while hydrophobicity increases. HMW PAHs have more recalcitrant structures and tend to be strongly adsorbed to sediment particles, thus increasing their persistence in the environment. Under permanent anoxia, PAHs were weakly depleted after 60 days (T4) (Fig. 2). PAH biodegradation is normally initiated by the introduction of oxygen atoms into the aromatic nucleus by oxygenases, but novel strategies that cope with the absence of dioxygen under anoxic conditions have recently been discovered (Fuch et al. 2011). According to field (e.g., Venosa et al. 1996) and fieldsimulating studies (e.g., Coates et al. 1996; Bregnard et al. 1996), anaerobic biodegradation exists for LMW
Fig. 4 Ordination analysis of banding pattern data in permanent oxic $(\mathrm{Ox})$, permanent anoxic (An), and in oscillating oxicanoxic (Osc) samples for sampling times T0 (initial sampling), T1 (15 days), T2 (30 days), T3 (45 days), and T4 (60 days). a Principal component analysis (PCA) based on bacterial class relative abundance. $\mathbf{b}$ Arrows point in the direction of maximal variation in species abundance, and arrow length is proportional to maximal rate of species change. Straight line indicates $60 \%$ similarity; broken line indicates $50 \%$ similarity
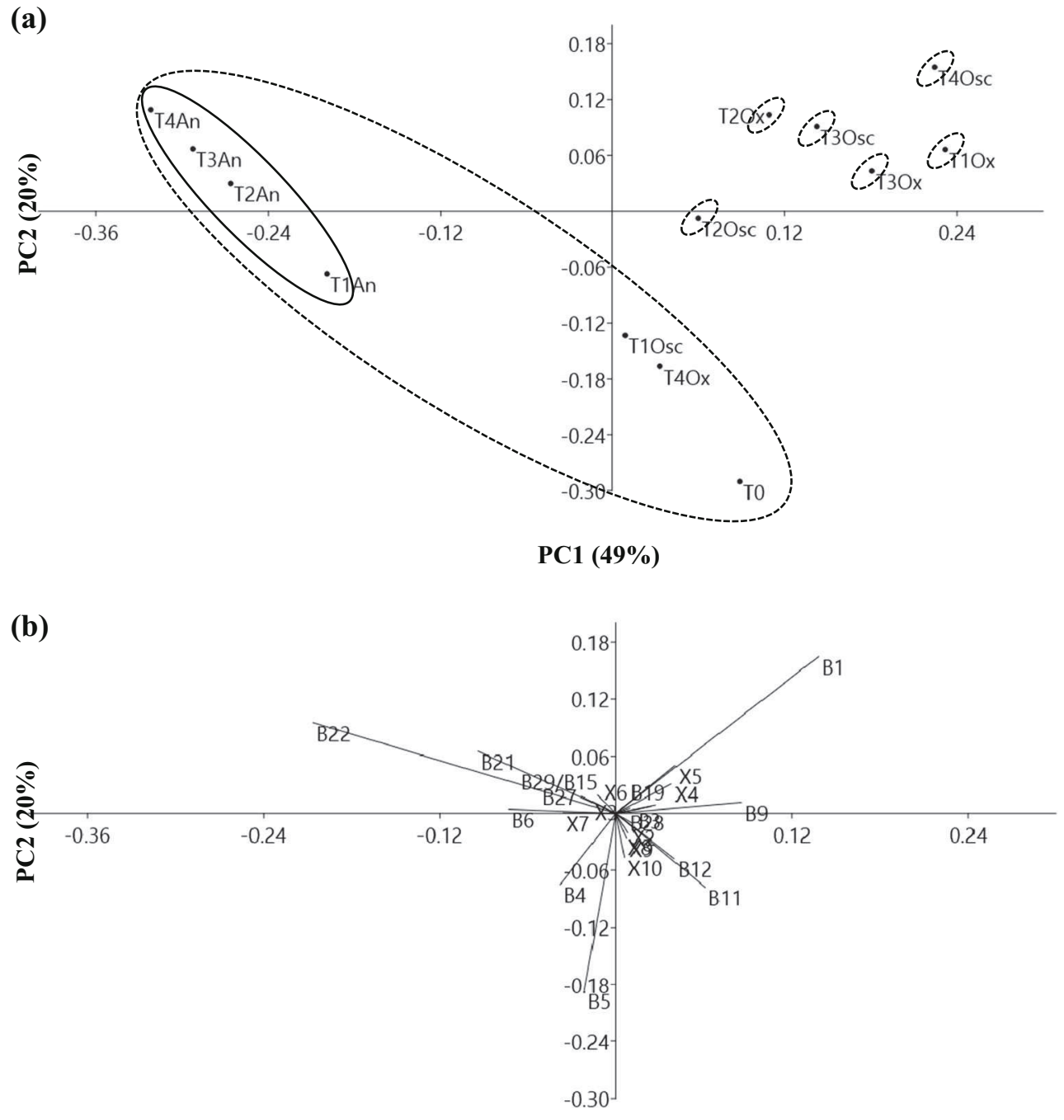
PAHs but is rarely observed for HMW PAHs in natural anoxic environments (Coates et al. 1997). Moreover, Hayes et al. (1999) suggested that microorganisms inhabiting sediments not contaminated with petroleum did not significantly oxidize PAHs under anaerobic conditions. Although the Aber Benoît basin of the northwestern coast of Brittany was polluted by an oil tanker spill in 1978 (Amoco-Cadiz), chemical analysis performed in the upper layer $(2 \mathrm{~cm})$ of the studied sediment detected only $4 \mathrm{mg}$ of biogenic HCs per gram of dry sediment (Stauffert et al. 2013). Even though the presence of $\mathrm{HC}$ induces selective pressures on microbial communities and may stimulate the community's tolerance to toxicants by the selection of favorable genotypes (Blanck and Dahl 1996), the absence of petrogenic $\mathrm{HC}$ in the sediment appears to explain the very low self-purification capacity of the LMW PAHs observed under anoxic conditions.

\section{Dynamics of bacterial assemblages under different oxygen regimes following a simulated oil spill}

The microbial assemblages of the sediments were studied at the beginning of the experiment (T0) and $15,30,45$, and 60 days (T1, T2, T3, and T4, respectively) after oil addition under the three different oxygen regimes. Changes in bacterial community structure were investigated using PCR-DGGE based on the $16 \mathrm{~S}$ rRNA gene. DGGE fingerprinting analysis is a useful method for following the dynamics of microbial communities in different ecosystems (e.g., Gomariz et al. 2014; Zhen et al. 2014) because it allows the direct determination of occurrence and relative frequency of the microbial ribotypes present at each sampling date (Fromin et al. 2002). Furthermore, associated ecological factors explaining the fingerprints can be determined based on the interpretation of these biological data (e.g., Bagi et al. 2014).

The PCA ordination based on the DGGE profiles of the total bacteria is shown in Fig. 4a. The first two principal components (PC1 and PC2) of the PCA explained $69 \%$ of the total variance. Separation of the bacterial communities along PC1 was significantly affected by the input of oxygen during the incubations. The PCA further revealed strong changes in the bacterial communities during the first 15 days of incubation, according to the oxygen regime to which they are subject, thus revealing an adaptation of the community to oxia, anoxia, and oscillating oxygen conditions. All samples subjected to anoxic conditions at 15, 30, 45, and 60 days (T1An, T2An, T3An, T4An, respectively) were clustered together (average similarity $61 \%$ ). DGGE patterns from anoxic samples were

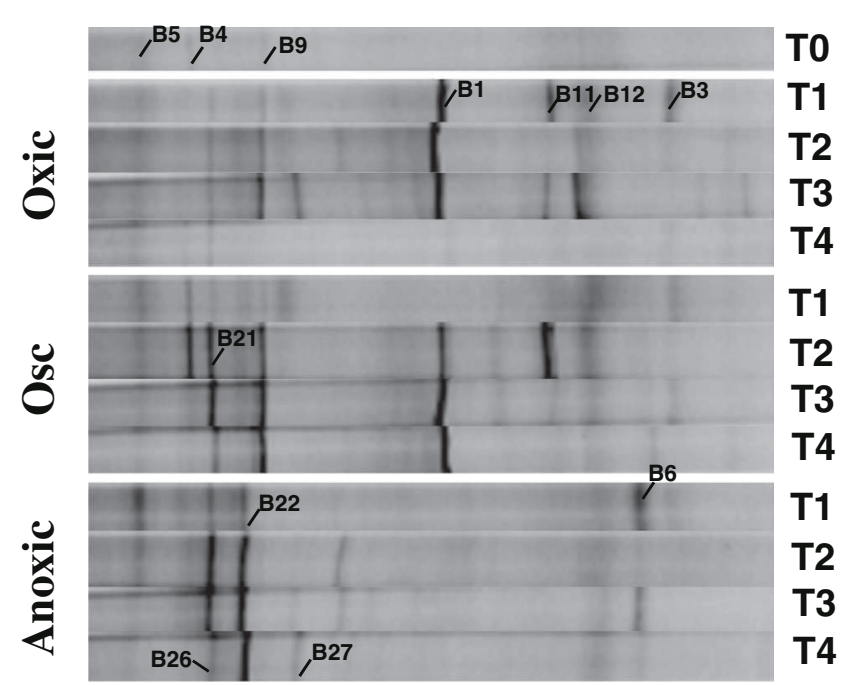

Fig. 5 DGGE patterns of bacterial communities in permanent oxic (Oxic), permanent anoxic (Anoxic), and in oscillating oxic-anoxic (Osc) samples for sampling times T0 (initial sampling), T1 (15 days), T2 (30 days), T3 (45 days), and T4 (60 days). Numbers indicate excised and sequenced bands

markedly different to those representing the first stages of bacterial assemblage dynamics under permanent oxic conditions. Permanently oxygenated samples were distributed in four different clusters, indicating significant changes in the composition of the bacterial communities during the first 45 days with a resilience of a portion of the bacterial populations at 60 days (Fig. 4a). These observations are in accordance with previous studies that showed rapid and significant changes of bacterial communities after $\mathrm{HC}$ addition in oxygenated environments (Röling et al. 2002; Alonso-Gutiérrez et al. 2009; Vitte et al. 2011, 2013). Resilience of bacterial populations after an oil spill event concomitant with a decrease of HC content in the contaminated environment has also been reported (Delille et al. 2002; Bordenave et al. 2007). Under oscillating oxygen conditions, an important shift of the bacterial community was observed only after 30 days. It is interesting to note that after 45 and 60 days under these conditions, the bacterial communities not only did show the highest similarity with the bacterial community observed after 15 days under permanent oxic conditions but also exhibited similar PAH removal.

Fig. 6 Distance phylogram of bacterial sequences based on aligned $16 \mathrm{~S}$ rRNA genes and 16S rRNA sequences (name in bold) from oilcontaminated sediments subjected to permanent oxygenation $(\mathrm{Ox})$, to permanent anoxia (An), and to oscillating oxic-anoxic conditions (Osc). Bootstrap values of $>70 \%$ (for 1000 iterations) are shown. The scale bar corresponds to 0.02 base substitutions per site 


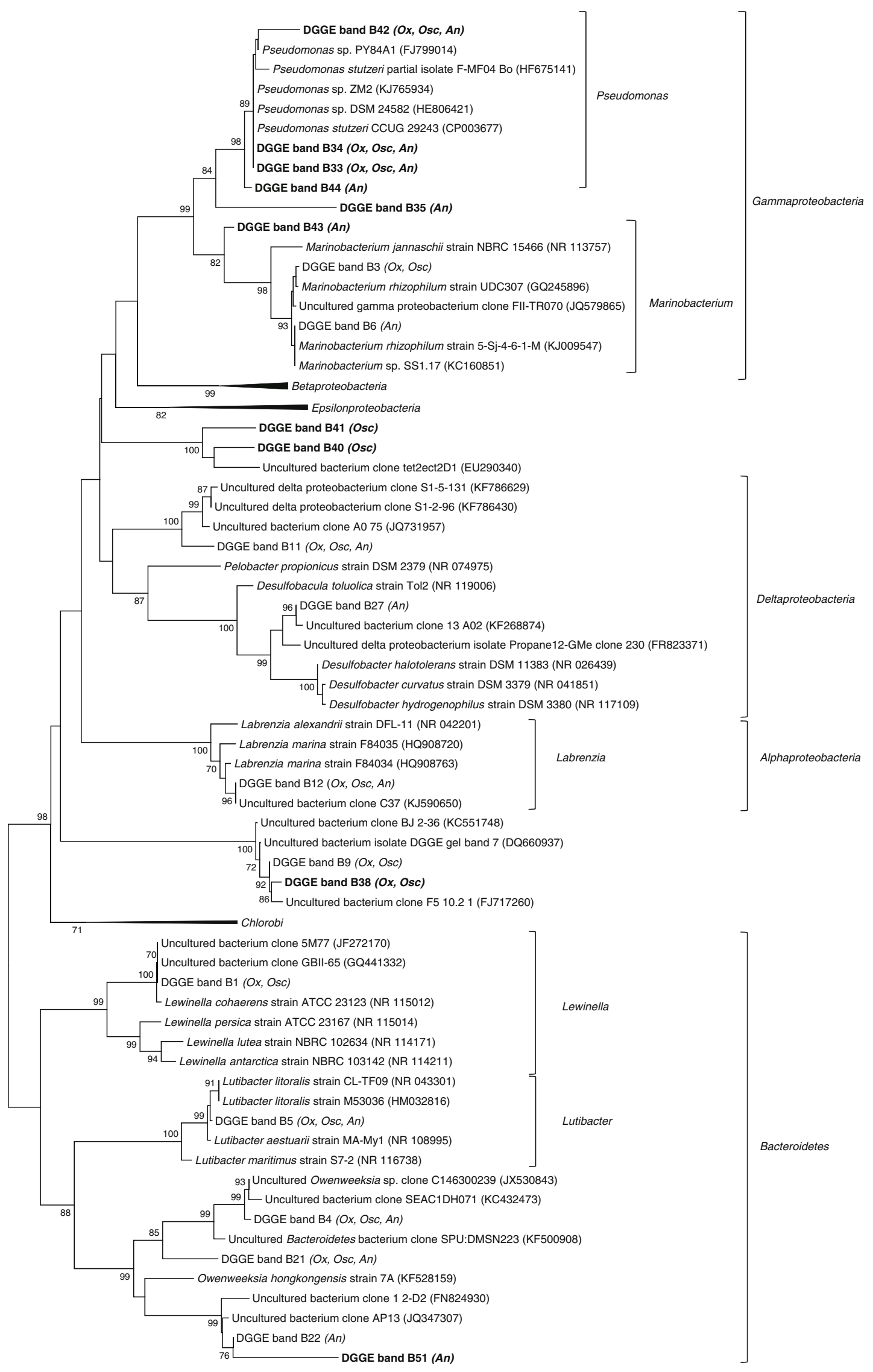




\section{Changes in dominant bacterial phylotypes during thin-layer incubations}

At the beginning of the experiment (T0), DGGE patterns revealed the species evenness of the bacterial population as evidenced by the lack of dominant phylotypes (Fig. 5). Sequence analyses (Fig. 6) showed the presence of an unidentified phylotype (B9) and of two phylotypes affiliated with Bacteroidetes: B5 with Lutibacter and B4 distantly related to Owenweeksia hongkongensis (KF528159: Flavobacteriia; Flavobacteriales; Cryomorphaceae; $92 \%$ identity). Monitoring of the bacterial communities under permanent oxic conditions showed a shift due to the setting up of the microcosms (including $\mathrm{HC}$ contamination) with four main phylotypes, which became dominant after 15 days (T1Ox). These early responders belong to the genera Labrenzia (B12), Lewinella (B1), and Marinobacterium (B3) and to the phylum Deltaproteobacteria (B11). With the exception of B3 and B11, these phylotypes were transiently dominant in the bacterial assemblage with a return to the basal level after 30 days. Blooms of several phylotypes belonging to Proteobacteria (e.g., Marinobacterium) and Bacteroidetes may have temporarily but strongly contributed to the microbial community in contaminated sites, as has been previously observed (Röling et al. 2004; Yakimov et al. 2005). From 30 days (T2), the relative abundance of the unidentified phylotype (B9) increased to become dominant after 45 days (T3). At the end of the experiment (T4), the DGGE pattern revealed a strong decrease of the dominant phylotypes in the bacterial assemblage. In microcosms subjected to oscillating oxic/ anoxic conditions, the early responders (with the exception of Marinobacterium) identified under continuously oxic conditions (T1Ox) were observed only after 30 days and were associated with a phylotype belonging to the Bacteroidetes (B21) and with two phylotypes observed during the initial sampling (unidentified Bacteroidetes: B4 and unidentified bacterium: B9). Throughout the experiment, the bacterial community was mainly composed of the unidentified Bacteroidetes (B21), Lewinella (B1), and the unidentified bacterium (B9). Under permanent anoxic conditions, specific phylotypes flourished during the experiment and were associated with phylotypes (B4 and B21) belonging to the Bacteroidetes observed under the other conditions (Fig. 4b). From 15 days (T1), phylotypes affiliated with Marinobacterium (B6), as well as an unidentified Bacteroidetes (B22), distantly related to O. hongkongensis (KF528159; $89 \%$ ), were observed (Fig. 4b). By the end of the experiment, a noticeable increase was recorded in the relative abundance of the deltaproteobacterial phylotype (B27), which is close to the sulfate-reducing hydrocarbonoclastic Desulfobacula toluolica (NR_119006; 96 \% identity). Thus, the presence of dioxygen in oily sediments drives the selection of specific phylotypes. During our incubations, the dynamics of the bacterial communities seems to be due to a combination of selective pressures exerted by the oxygen regime together with the utilization of $\mathrm{HC}$ substrates by adapted bacteria.

\section{Characterization of metabolically active bacteria}

Only a minority of the phylotypes present in the 16S rRNA gene fingerprints were identical to those present in the fingerprints obtained from $16 \mathrm{~S}$ rRNA. In general, metabolically active and growing bacteria contain more rRNA molecules from ribosomes than do resting or starved bacterial cells (Nomura et al. 1984). Thus, the use of a dual 16S rRNA/ 16S rRNA gene approach allowed the identification of microorganisms that were presumably metabolically active, particularly those involved in the response to oil within the whole bacterial assemblages. Clustering analysis comparing the DGGE patterns from active bacteria revealed a separation of the samples into five clusters when an average similarity of $60 \%$ was considered (Fig. 7). The first cluster (cluster II) was composed solely of the time zero sample (T0) and showed an average similarity of $50 \%$ with the "early-stage cluster" (cluster I), which was made up of highly similar band profiles (average similarity: $94 \%$ ) from the first sampling times (T1 and $\mathrm{T} 2$, irrespective of the oxygenation regime). This observation indicates a shift of the active bacterial communities during the first 2 weeks, certainly due to crude oil contamination and an adaptation of the community to the experimental conditions. After 2 weeks (T1), the most active phylotypes were affiliated with Pseudomonas (B33, B34), Labrenzia (B12), and with an unidentified Deltaproteobacteria (B11) (Fig. 6). Thirty days after contamination (T2), these phylotypes were associated with an unidentified bacterium (B38) under both oscillating oxic/anoxic and permanent oxic conditions. B38 is distantly related to Alkaliphilus metalliredigens (NR_074633: Firmicutes; Clostridia; Clostridiales; Clostridiaceae; $87 \%$ ) and Desulfomicrobium baculatum (CP001629: Proteobacteria; Deltaproteobacteria; Desulfovibrionales; Desulfomicrobiaceae; 83 \%) suggesting that this phylotype is a novel lineage. Under these oxygenation regimes, a sharp modification of the relative abundance of the dominant active phylotypes was observed at 45 and 60 days. This observation was in accordance with the clustering analysis showing that the samples T3Ox, T3Osc, T4Ox, and T4Osc were grouped in the cluster III when B38 was highly active (Fig. 7). Coincidentally, the greatest change in the abundance of phylotype B38 occurred during the final 15 days, the period during which LMW PAH biodegradation rates were the most significant for the permanent oxic and the oscillating oxygen conditions. Nonetheless, without uncontaminated control, it cannot be discarded that these changes in the community are not also linked to an adaptation to the experimental conditions. It should be noted, however, that other studies provide evidence of a drastic increase of $16 \mathrm{~S}$ 


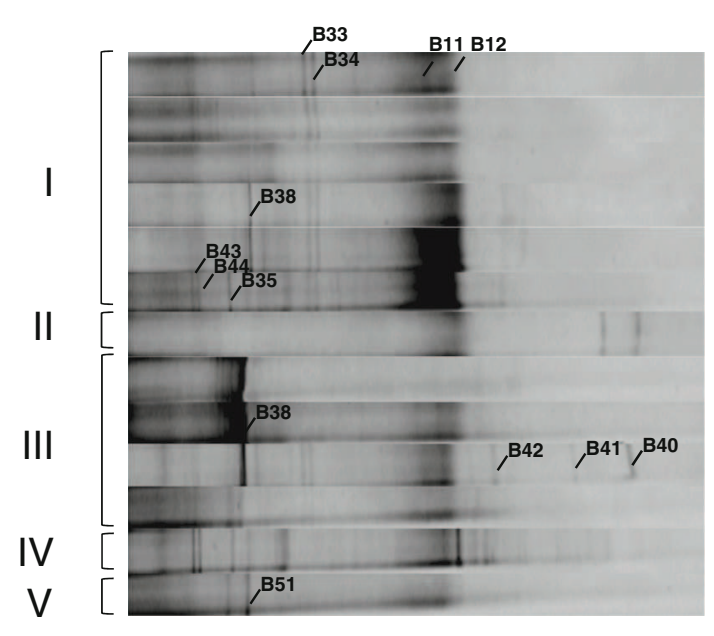

Fig. 7 Cluster analysis of DGGE profiles of active bacterial communities in permanent oxic (Ox), permanent anoxic (anoxic), and in oscillating oxic-anoxic (Osc) samples for sampling times T0 (initial sampling), T1

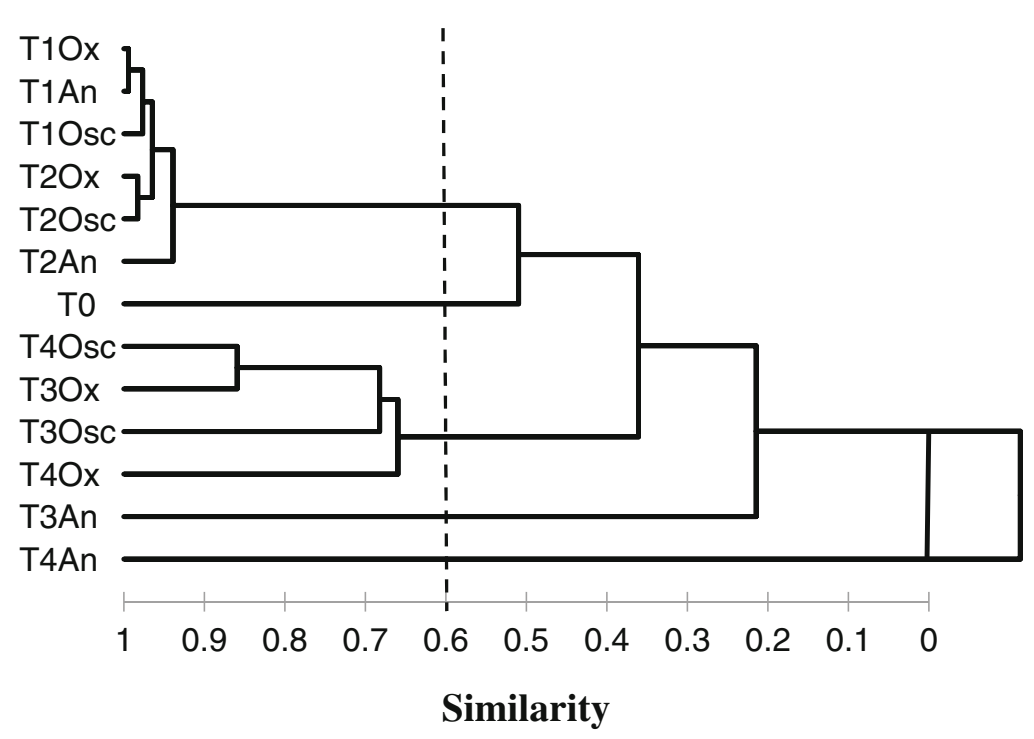

(15 days), T2 (30 days), T3 (45 days), and T4 (60 days). Numbers indicate excised and sequenced bands

determine the succession from aliphatic HC-degrading bacteria to those utilizing aromatic HCs. initial phase of oil degradation (Röling et al. 2004; Vitte et al. 2011). Several strains of Pseudomonas have shown ability to degrade a number of aliphatic and (poly)aromatic HCs in pure culture (Mulet et al. 2011), in simplified communities (Singleton et al. 2005) or in complex in situ communities (Kostka et al. 2011). More recently, members of the genus Labrenzia were isolated under aerobic conditions from beach sands contaminated during the Deepwater Horizon oil spill (Overholt et al. 2013). Members of this genus are all considered to be chemoheterotrophic and non-fermentative facultative anaerobes. Under permanent anoxic conditions at T2, active bacteria were associated with Pseudomonas (B33, B34), Labrenzia (B12), and with members of Deltaproteobacteria (B11). Other phylotypes belonged to the order Pseudomonadales and the genus Marinobacterium: B35 (Pseudomonas stutzeri CP007509; $91 \%$ ), B44, (Pseudomonas sp. KJ765934; $99 \%$ ), and B43 (Marinobacterium rhizophilum GQ245896; 96 \%). Finally, cluster IV and cluster V were related to last incubation times (T3An and T4An, respectively), underlining the fact that a succession of active bacteria occurred in anoxia during the last 15 days, when the LMW PAH removal began. The most active bacteria belonged to Marinobacterium (B43) and to the Pseudomonadales (B44 and B35) after 45 days. After 60 days, sequences related to Pseudomonadales (B35) and to an unidentified Bacteroidetes (B51), showing closest sequence similarity to O. hongkongensis (KF528159: Flavobacteriia; Flavobacteriales; Cryomorphaceae; $86 \%$ ), were the most active. Further study is needed to confirm that these phylotypes are involved in $\mathrm{HC}$ removal and, in any case, to

\section{Conclusions}

Under field-realistic conditions and after 60 days of incubation, permanent oxygenation resulted in the greatest PAH removal from oiled sediments, and oscillating regimes produced results similar to continuous anoxic conditions. Under oscillating oxygen conditions, 60 days were required to remove as much PAH as after 15 days under permanent oxic conditions. At the same time, very low PAH removal was observed after 60 days under permanent anoxic conditions. Moreover, without sediment resuspension, the effectiveness of intermittent aeration on $\mathrm{HC}$ removal seemed to be drastically reduced when compared with the oil sludge process (Vieira et al. 2009; Vitte et al. 2011, 2013). Pseudomonas spp., Labrenzia sp., and an unidentified Deltaproteobacteria were involved in the early response to perturbation due to oil contamination and the setting up of the microcosm irrespective of the oxygen regime, followed by the selection of late responders which were specifically adapted to the oxygen regime. The phylotype B38, distantly related to A. metalliredigens and D. baculatum, was highly active during the last stage of the experiment when the LMW PAH biodegradation rates were significant for permanent oxic and oscillating oxygen conditions, suggesting that this novel phylotype could play a role in biodegradation. This work has provided complementary knowledge on $\mathrm{HC}$ removal by potential HC-degrading candidates in coastal marine sediment as subjected to permanent 
oxic conditions, to relatively slow oxic-anoxic switches (3 days oxic/3 days anoxic), and to permanent anoxic conditions without sediment stirring. Because coastal marine sediments are subject to contrasted oxic conditions depending on tidal excursions, hydrodynamics, and the presence of bioturbating organisms, it is critical to determine $\mathrm{HC}$ fate in these ecosystems under different oxygenation schemes. Through bioturbation, dwelling macrofauna induces faster patterns of oxygen introduction in the anoxic sediments (e.g., $10 \mathrm{~min}$ oxic/20 min without oxygen input, Alitta virens irrigation rhythm; Kristensen 1989). For this purpose, further studies are required to decipher microbial interactions and their role in $\mathrm{HC}$ degradation in coastal marine sediments subject to faster oxygen fluctuations.

Acknowledgments This research was funded by the French National Agency (ANR) under the DHYVA (ANR 2006 SEST 09) and DECA PAGE (ANR 2011 CESA 006 01) projects. We thank Patricia Bonin for many fruitful and interesting exchanges.

Conflict of interest The authors declare that the research was conducted in the absence of any commercial or financial relationships that could be construed as a potential conflict of interest.

\section{References}

Abril G, Commarieu MV, Etcheber H, Deborde J, Deflandre B, Živađinović MK, Chaillou G, Anschutz P (2010) In vitro simulation of oxic/suboxic diagenesis in an estuarine fluid mud subjected to redox oscillations. Estuar Coast Shelf Sci 88:279-291

Aller RC (1994) Bioturbation and remineralization of sedimentary organic matter: effects of redox oscillation. Chem Geol 114:331-345

Alonso-Gutiérrez J, Figueras A, Albaigés J, Jiménez N, Viñas M, Solanas AM, Novoa B (2009) Bacterial communities from shoreline environments (Costa da Morte, northwestern Spain) affected by the prestige oil spill. Appl Environ Microbiol 75:3407-3418

Altschul SF, Gish W, Miller W, Myers EW, Lipman DJ (1990) Basic local alignment search tool. J Mol Biol 215:403-410

Alzaga R, Montuori P, Ortiz L, Bayona JM, Albaiges J (2004) Fast solidphase extraction-gas chromatography-mass spectrometry procedure for oil fingerprinting. Application to the Prestige oil spill. J Chromatogr A 1025:133-138

Bagi A, Pampanin DM, Lanzén A, Bilstad T, Kommedal R (2014) Naphthalene biodegradation in temperate and arctic marine microcosms. Biodegradation 25:111-125

Bastviken D, Persson L, Odham G, Tranvik L (2004) Degradation of dissolved organic matter in oxic and anoxic lake water. Limnol Oceanogr 49:109-116

Blanck H, Dahl B (1996) Pollution-induced community tolerance (PICT) in marine periphyton in a gradient of tri- n-butyltin (TBT) contamination. Aquat Toxicol 35:59-77

Bordenave S, Goñi-Urriza MS, Caumette P, Duran R (2007) Effects of heavy fuel oil on the bacterial community structure of a pristine microbial mat. Appl Environ Microbiol 73:6089-6097

Bregnard T, Hoehener P, Haener A, Zeyer J (1996) Degradation of weathered diesel fuel by microorganisms from a contaminated aquifer in aerobic and anaerobic microcosms. Environ Toxicol Chem 15:299_ 307
Cerniglia CE, Heitkamp MA (1989) Microbial degradation of polycyclic aromatic hydrocarbons in the aquatic environment. In: Varanasi $\mathrm{U}$ (ed) Metabolism of polycyclic aromatic hydrocarbons in the aquatic environment. CRC Press, Boca Raton, pp 41-68

Coates JD, Anderson RT, Woodward JC, Phillips EJP, Lovley DR (1996) Anaerobic hydrocarbon degradation in petroleum contaminated harbor sediments under sulfate-reducing and artificially imposed ironreducing conditions. Environ Sci Technol 30:2764-2769

Coates JD, Woodward J, Allen J, Philp P, Lovley DR (1997) Anaerobic degradation of polycyclic aromatic hydrocarbons and alkanes in petroleum-contaminated marine harbor sediments. Appl Environ Microbiol 63:3589-3593

Cuny P, Cravo-Laureau C, Grossi V, Gilbert F, Militon C (2011) Biodegradation of hydrocarbons in bioturbated marine sediments. In: Koukkou AI (ed) Microbial bioremediation of non-metals: current research. Caster Academic Press, Norfolk, pp 55-92

Delille D, Delille B, Pelletier E (2002) Effectiveness of bioremediation of crude oil contaminated subantarctic intertidal sediment: the microbial response. Microb Ecol 44:118-126

Fromin N, Hamelin J, Tarnawski S, Roesti D, Jourdain-Miserez K, Forestier N, Teyssier-Cuvelle S, Gillet F, Aragno M, Rossi P (2002) Statistical analysis of denaturing gel electrophoresis (DGE) fingerprinting patterns. Environ Microbiol 4:634-643

Fuch G, Boll M, Heider J (2011) Microbial degradation of aromatic compounds - from one strategy to four. Nat Rev Microbiol 9:803816

Gilbert F, Stora G, Bertrand JC (1996) In situ bioturbation and fate in an experimental contaminated Mediterranean coastal ecosystem. Chemosphere 33:1449-1458

Gomariz M, Martínez-García M, Santos F, Rodriguez F, CapellaGutiérrez S, Gabaldón T, Rosselló-Móra R, Meseguer I, Antón J (2014) From community approaches to single-cell genomics: the discovery of ubiquitous hyperhalophilic Bacteroidetes generalists. ISME J. doi:10.1038/ismej.2014.95

Grossi V, Massias D, Stora G, Bertrand JC (2002) Burial, exportation and degradation of acyclic petroleum hydrocarbons following a simulated oil spill in bioturbated Mediterranean coastal sediments. Chemosphere 48:947-954

Hayes LA, Nevin KP, Lovley DR (1999) Role of prior exposure on anaerobic degradation of naphthalene and phenanthrene in marine harbor sediments. Org Geochem 30:937-945

Head IM, Jones DM, Roling WF (2006) Marine microorganisms make a meal of oil. Nat Rev Microbiol 4:173-182

Hylland K (2006) Polycyclic aromatic hydrocarbon (PAH) ecotoxicology in marine ecosystems. J Toxicol Environ Health 69:109-123

Kimura M (1980) A simple method for estimating evolutionary rate of base substitutions through comparative studies of nucleotide sequences. J Mol Evol 16:111-120

Kostka JE, Prakash O, Overholt WA, Green SJ, Freyer G, Canion A et al (2011) Hydrocarbon-degrading bacteria and the bacterial community response in Gulf of Mexico beach sands impacted by the Deepwater Horizon oil spill. Appl Environ Microbiol 77(22): 7962-7974

Kristensen E (1989) Oxygen and carbon dioxide exchange in the polychaete Nereis virens: influence of ventilation activity and starvation. Mar Biol 101:381-388

Kristensen E, Ahmed SI, Devol AH (1995) Aerobic and anaerobic decomposition of organic matter in marine sediment: which is fastest? Limnol Oceanogr 40:1430-1437

Lane DJ, Pace B, Olsen GJ, Stahl DA, Sogin ML, Pace NR (1985) Rapid determination of $16 \mathrm{~S}$ ribosomal RNA sequences for phylogenetic analyses. Proc Natl Acad Sci U S A 82:6955-6959

Lane DJ (1991) 16/23S rRNA sequencing. In: Stackerbrandt E, Goodfellow M (eds) Nucleic acid techniques in bacterial systematics. Wiley, New York, pp 115-175 
Latimer JS, Davis WR, Keith DJ (1999) Mobilization of PAHs and PCBs from in-place contaminated marine resuspension events. Estuar Coast Mar Sci 49:577-595

Lê S, Josse J, Husson F (2008) FactoMineR: an R package for multivariate analysis. J Stat Softw 25:1-18

Leahy JG, Colwell RR (1990) Microbial degradation of hydrocarbons in the environment. Microbiol Rev 54(3):305-315

LeBlanc L, Gulnick JD, Brownawell BJ, Taylor GT (2006) The influence of sediment resuspension on the degradation of phenanthrene in flow-through microcosms. Mar Environ Res 61:202-223

Löser C, Seidel H, Zehnsdorf A, Stottmeister U (1998) Microbial degradation of hydrocarbons in soil during aerobic/anaerobic changes and under purely aerobic conditions. Appl Microbiol Biotechnol 49: 631-636

Meckenstock RU, Mouttaki H (2011) Anaerobic degradation of nonsubstituted aromatic hydrocarbons. Curr Opin Biotechnol 22:406414

Miralles G, Grossi V, Acquaviva M, Duran R, Bertrand JC, Cuny P (2007) Alkane biodegradation and dynamics of phylogenetic subgroups of sulfate-reducing bacteria in an anoxic coastal marine sediment artificially contaminated with oil. Chemosphere 68(7):13271334

Mulet M, David Z, Nogales B, Bosch R, Lalucat J, García-Valdés E (2011) Pseudomonas diversity in crude-oil-contaminated intertidal sand samples obtained after the Prestige oil spill. Appl Environ Microbiol 77(3):1076-1085

Muyzer G, De Waal EC, Uitierlinden AG (1993) Profiling of complex microbial populations by denaturing gradient gel electrophoresis analysis of polymerase chain reaction-amplified genes coding for 16S rRNA. Appl Environ Microbiol 59(3):695-700

Nikolaou A, Kostopoulou M, Lofrano G, Meric S, Petsas A, Vagi M (2009) Levels and toxicity of polycyclic aromatic hydrocarbons in marine sediments. Trends Anal Chem 28:653-664

Nomura M, Gourse R, Baugham G (1984) Regulation of synthesis of ribosomes and ribosomal components. Annu Rev Biochem 53:75-117

Overholt WA, Green SJ, Marks KP, Venkatraman R, Prakash O, Kostka JE (2013) Draft genome sequences for oil-degrading bacterial strains from beach sands impacted by the Deepwater Horizon oil spill. Genome Announc 1(6):e01015-13

Pérez-Pantoja D, González B, Pieper DH (2010) Aerobic degradation of aromatic hydrocarbons. In: Timmis KN (ed) Handbook of hydrocarbon and lipid microbiology. Springer-Verlag Berlin Heidelberg, Berlin, pp 799-837

Pischedda L, Poggiale JC, Cuny P, Gilbert F (2008) Imaging oxygen distribution in marine sediments. The importance of bioturbation and sediment heterogeneity. Acta Biotheor 56:123-135

Rojo F (2010) Enzymes for aerobic degradation of alkanes. In: Timmis KN (ed) Handbook of hydrocarbon and lipid microbiology. Springer-Verlag Berlin Heidelberg, Berlin, pp 781-798

Röling WF, Milner MG, Jones DM, Lee K, Daniel F, Swannell RJ, Head IM (2002) Robust hydrocarbon degradation and dynamics of bacterial communities during nutrient-enhanced oil spill bioremediation. Appl Environ Microbiol 68:5537-5548

Röling WF, Milner MG, Jones DM, Fratepietro F, Swannell RP, Daniel F, Head IM (2004) Bacterial community dynamics and hydrocarbon degradation during a field-scale evaluation of bioremediation on a mudflat beach contaminated with buried oil. Appl Environ Microbiol 70(5):2603-2613
Saitou N, Nei M (1987) The neighbour-joining method: a new method for reconstructing phylogenetic trees. Mol Biol Evol 4:406-425

Singleton DR, Powell SN, Sangaiah R, Gold A, Ball LM, Aitken MD (2005) Stable-isotope probing of bacteria capable of degrading salicylate, naphthalene, or phenanthrene in a bioreactor treating contaminated soil. Appl Environ Microbiol 71(3):1202-1209

Stauffert M, Cravo-Laureau C, Jézéquel R, Barantal S, Cuny P, Gilbert F, Cagnon C, Militon C, Amouroux D, Mahdaoui F, Bouyssiere B, Stora G, Merlin FX, Duran R (2013) Impact of oil on bacterial community structure in bioturbated sediments. PLoS One 8(6): e 65347

Sun M, Lee C, Aller RC (1993) Laboratory studies of oxic and anoxic degradation of chlorophyll-a in Long Island Sound sediments. Geochim Cosmochim Acta 57:147-157

Sun MY, Aller RC, Lee C, Wakeham SG (2002) Effects of oxygen and redox oscillation on degradation of cell-associated lipids in surficial marine sediments. Geochim Cosmochim Acta 66:2003-2012

Tamura K, Peterson D, Peterson N, Stecher G, Nei M, Kumar S (2011) MEGA5: molecular evolutionary genetics analysis using maximum likelihood, evolutionary distance, and maximum parsimony methods. Mol Biol Evol 28:2731-2739

Thompson JD, Higgins DG, Gibson TJ (1994) CLUSTAL W: improving the sensitivity of progressive multiple sequence alignment through sequence weighting, position-specific gap penalties and weight matrix choice. Nucleic Acids Res 22:4673-4680

Yakimov MM, Denaro R, Genovese M, Cappello S, D'Auria G, Chernikova TN, Timmis KN, Golyshin PN, Giluliano L (2005) Natural microbial diversity in superficial sediments of Milazzo Harbor (Sicily) and community successions during microcosm enrichment with various hydrocarbons. Environ Microbiol 7:14261441

Vieira PA, Vieira RB, Faria S, Ribeiro EJ, Cardoso VL (2009) Biodegradation of diesel oil and gasoline contaminated effluent employing intermittent aeration. J Hazard Mater 168:1366-1372

Venosa A, Suidan M, Wrenn B, Strohmeier K, Haines J, Eberhart B, King DHE (1996) Bioremediation of an experimental oil spill on the shoreline of Delaware Bay. Environ Sci Technol 30:1764-1775

Vitte I, Duran R, Jézéquel R, Caumette P, Cravo-Laureau C (2011) Effect of oxic/anoxic switches on bacterial communities and PAH biodegradation in an oil-contaminated sludge. Environ Sci Pollut Res 18: 1022-1032

Vitte I, Duran R, Hernandez-Raquet G, Mounier J, Jézéquel R, Bellet V, Balaguer P, Caumette P, Cravo-Laureau C (2013) Dynamics of metabolically active bacterial communities involved in PAH and toxicity elimination from oil-contaminated sludge during anoxic/oxic oscillations. Appl Microbiol Biotechnol 97:4199-4211

Wakeham SG, Canuel EA (2006) Degradation and preservation of organic matter in marine sediments. In: Edited Volkman JK (ed) Handbook of environmental chemistry. Springer Berlin Heidelberg Berlin, Germany, pp 295-321

Wright ES, Safak Yilmaz L, Noguera DR (2012) DECIPHER, a searchbased approach to chimera identification for 16S rRNA sequences. Appl Environ Microbiol 78:717-725

Zhen Z, Liu H, Wang N, Guo L, Meng J, Ding N, Wu G, Jiang G (2014) Effects of manure compost application on soil microbial community diversity and soil microenvironments in a temperate cropland in china. PLoS One 9(10):e108555 